\title{
In Search of Wilderness
}

\author{
by
}

\author{
Mike Halleran²
}

With the rising concern for overall environmental quality has come an increased concern for wilderness. Definitions of the term have proliterated also. For some, the only true wilderness is a place where no man has ever been. One definition in that spirit notes that; "a wilderness is a place where the hand of man has never set foot" By that definition I am guilty of having personally destroyed some wilderness here in $\mathrm{BC}$ because I have been to some places where I believe I was the first to go there, thus spoiling it for the purists forever.

There is also a much less conservative position. While riding through Golden Ears Park one time I met a family of hikers on one of the riding trails. A bright, healthylooking lady asked me if I was enjoying "the wilderness". She had not noticed. or did not care, that the horse trail on which we met was actually an old logging railway. She had obviously failed to notice the rusting steel cables hiding among the sword ferns.

In that part of the park, one of the heaviest use parks in the whole province, the second-growth forest contains trees of up to a meter in diameter but there are still lots of spring-board stumps. The fact is that Golden Ears was logged flat about a century ago ... peeled like an orange it was ... have seen the pictures. Now, there are those who regard it as wilderness.

Of course, one can be disillusioned in many ways. On a helicopter trip up the east side of the Alaskan Panhandle several years ago our pilot landed on an alpine ridge and shut the machine down so we could enjoy lunch with a commanding view. After lunch, the pilot and I sat talking while my cameraman explored our little

'A talk prepared for the Wilderness Symposium of the Outdoor Recreation Council of BC, 28/May/1983

2Mike Halleran is a long-time journalist, film maker and broadcaster. He has worked as a producer of natural resources documentaries for the CBC: a columnist on the outdoors for various magazines and periodicais; a wildlife writer for the Vancouver Sun. He has made freelance films on forestry. wildife, tisheries and range management tor the $\mathrm{CBC}$, the National Film Board and for various resource man agement agencies He is now employed as Director of Communications with the Department of Fisheries and Oceans (Canada) and lives in Vancouver sanctuary. He came back shortly, wearing a smug smile, hands behind his back, obviously concealing some trophy or other. It turned out that we were not the first to enjoy lunch on that particular spot. $\mathrm{He}$ had found a discarded Kentucky Fried Chicken container

I watched a documentary film on Algonquin Park recently. Many of the people interviewed said they regarded Algonquin Park as wilderness. For some reason more women than men had that opinion. Yet parts of the park are being logged and public use generally has reached such intensity that severe crowding is taking place.

Life Magazine did a feature on major US parks about ten years ago. They noted the crime problems, the vandalism and pollution problems. They interviewed one park employee whose items of office included a can of mace, a 38 revolver and a degree in botany.

I have trouble defining wilderness myself. For me it is more a sensation than something I can fit into a cliche. If I have been "too long in city pent" as the poet said, just a walk in a quiet forest or a few hours by a streamside will do wonders for me. I sometimes drive to an alpine meadow not far from my home, using an old mining road for access. It is a fine piece of country with typical alpine brooks and pothole lakes, acres of purple heathers, alpine larch and limber pine are in abundance. It feels really good up there but if I had the time I would go a couple of skylines farther back to leave all human activity behind. Is a wilderness a place you can drive to? People in Algonquin Park seem to think so. The lady in Golden Ears Park also thinks so. For what its worth, I do not agree with them.

My own association with wilderness campaigns goes back quite a long ways. For many years I worked as a television producer with the CBC. I made programs on resources and environmental matters exclusively. In two programs I took a strong editorial position in favor of establishing the Purcell Wilderness. I received a lot of abusive response, several personal threats and survived a campaign to get me fired. The experience taught me that single-issue campaigning was the wrong way to address the wilderness question.

I do a lot of public speaking, most of it at environmental or resources conferences such as this one. Writing this talk was one of the most difficult things I have done in a long time. I wanted it to be constructive yet I know it can't be that unless it is also critical. I opted for the "let it all hang out" approach for I think it's time for open discussion on this matter.

A lot of wilderness advocates sound to me like they are anti-industry. I am not in that category. Sometimes I think criticisms of the way our resources are managed are based more on individual human value judgements than ecological reality. It would seem to me that "ugly" is also in the eye of the beholder. I am not offended by logging, hunting, cattle grazing or commercial fishing. I get good feelings when I see these activities happening and I am reminded that over half the people on earth live in places where it is not possible to do any of those things.

None of that prevents me from despising bad logging, slob hunters, overgrazing or overfishing. I wish there was a greater realization of the enormous dependency we have on all our renewable resources for I think that would help get for them, the level of fiscal support the management and husbandry of these resources requires.

There is a tendency on the part of some citizens to have what almost amounts to a guilt complex about using our natural resources. I think we should feel guilty about abusing them but we have no choice but to use them and we all do that. There are no non-consumers today.

I believe one can believe emphatically in the principle of wilderness and not automatically support every single wilderness proposal. But some wilderness advocates, like some environmentalists, take themselves so seriously that one is regarded with suspicion, even contempt, if one does not agree with everything they do. The debate has become so overheated, so screeching at times, full of threats and ultimatums, that it is hard to find any middle ground. We must try and change that. 
There are radical positions on all sides from time to time. We have heard enough from each of them. Industry still has some classically red-necked positions but there are environmental red-necks too. Some of these promote the simplistic notion that involvement with industry renders one ineligible to discuss the environmental crisis. You have to learn to recognize these people. When you encounter them in other organizations, go around them. If you have some of your own, learn to control them. Militancy is not always the best tactic to successful conservation campaigning These people can hurt your cause today.

That could all change of course and at sometime in the future we could be all back into the unproductive process of adversary campaigning but that should be the last option you go to, not the first.

As I attempt to find a word that will best define the psychological character of the classic wilderness campaigner there is one that keeps coming up. The word is naive.

There seems to be little recognition that the wilderness debate must be broadened and considered as a province-wide and crucial social question not just a recreation question. This objective will never be satisfied by having a couple of dozen separate campaigns all underway at the same time. That process is destructive and turns people of common purpose into competitors.

With the Valhalla issue decided will that do anything for the campaigns for South Moresby or the Cascades? The answer is no. In fact, the very reverse may be true.

I followed the Valhalla campaign with interest. I have known the Slocan Valley for over 40 years. It is a beautiful place now undergoing a dramatic alteration in social temperature as a consequence of large influxes of people. So I was amazed that during the Valhalla campaign, wilderness advocates argued that their favorite option would create more jobs than the logging option. That is a negative argument for me. The numbers reported in the press were somewhere around 15 jobs in forestry versus over 200 associated with the park option. I would have had to vote against the park on that basis alone. The Slocan Valley has some charming, natural, quiet, rural and desireable qualities which all contribute to the attractive lifestyle. More people won't make it better.

A lot of the urgency in the current wilderness conflict stems from a belief that we are running out of wilderness. Again, this is an event that moves me to describe some of the wilderness discussion as "naive". We do face a real crisis with regard to setting land use priorities on prime forest land but there are other pieces of wilderness in BC that are currently under no pressure at all.

This attitude could be likely traced to the fact that over 90 percent of the people in $B C$ live in the lower half of the province. They seem to want their wilderness close to home. So their demands cause real uncertainty and real problems for the forestry establishment since demand for that resource is rising also.
The northern half of $\mathrm{BC}$ contains vast areas of what I would describe as pure wilderness. There is no sense of urgency to establish wilderness areas there but 1 suggest that a province-wide perspective is needed if we are to address concerns over the so-called "vanishing wilderness"

I want to prove something to myself here so I would like to ask this audience a question. How many people in this room have ever heard of the Kawdi Plateau?

Let me identify it for you. It is bounded roughtly by the Telegraph Creek - Cassiar Highway on the south and east; by the Alaskan Panhandle on the west; and the town of Atlin and the Yukon Border are principle features on its northern boundary. The area contained within these boundaries is about the size of Vancouver Island.

The plateau is the source for several major rivers such as the Taku, the Teslin, the Nahlin, the Tuya and others. It has glaciers, wooded valleys, gently rolling alpine grasslands, pristine lakes by the score (some of them still unnamed) and an abundant wildlife population. The area contains virtually no roads, no towns, industrial presence or human settlement. It is larger than all of BC's provincial parks combined.

We could all form a "save the Kawdi" society and if we did, we would likely begin by seeking to have media publicize our case. As one with close to 20 years in media, most of it specializing in outdoors, conservation and resources journalism, I can tell you that this approach is pretty naive as well.

It may also be somewhat selfish for as we tried for media coverage for this campaign we would lessen the likelihood that other campaigners would get equal time. In fact, we had better hope that the media doesn't go for equal time. Equal time would mean so little mention for our proposal that by the time media has looked at all 20 or more, we wouldn't get enough to matter. Nobody would.

There are some basic shortcomings with attempting to have wilderness by lobby alone. The more campaigns there are, the less chance you have of winning yours. The public and government will have lost interest long before they have heard from a couple of dozen proposals. Allow me to let you in on something else. The press is yawning already.

In practice, the Valhalla group ended up campaigning not only against forestry in the Valhalla mountains but in effect, against wilderness proposals elsewhere. In a media blitz they sent people to Vancouver to lobby all the major media.

They managed to get front page and prime time coverage for their special interest but it meant that no editor could justify devoting such profile to any other wilderness area for a good long time. Accept it. Wilderness is not big news.

These difficulties are all hazards of relying on lobby efforts alone as a means of getting satisfaction for any special interest and like it or not, wilderness campaigners represent a "special interest". Again, the word "naive" occurs to me

Professional lobbyists all understand that you win some and you lose some. Because there is so seldom any middle ground, the tyranny of "either - or" decisions is the likely result from relying on lobby process alone. To be realistic, you must see that ultimately, you will end up fighting each other. I see the Valhalla experience as evidence of that.

In my opinion, wilderness is usually opposed because it is the hardest kind of land use to accomodate. That is because wilderness is single use. Like it or not, wilderness can deny almost as many land uses as a hydro dam or a strip mine. Grazing, logging, mining, hunting, the use of 4-wheel drive vehicles, snowmobiles or trail bikes are all outdoor activities permitted and encouraged in a provincial forest but restricted or not allowed in a wilderness. When we establish a wilderness area we convert a piece of public land from multiple use to single use and that is why it is so often opposed.

Wilderness groups will lose credibility by condemning the (sometimes) single uses promoted by some industries when they are bent on imposing another kind of single use themselves. Single use at worst implies that only one land use would be permitted and at best implies that one special interest will be allowed to maximize its activities there. Experienced observers of land use allocation know that the only way to maximize one resource value is at the expense of the others. That is a social as well as a biological fact.

It is no secret that the forest industry now faces a serious problem of maintaining a wood supply. Managing this resource presents some enormous social and ecological challenges. But when the extent of the forest inventory is continually being eroded for other uses and the game plan is continually being changed, that causes great uncertainty. It is almost axiomatic that if land is required for non-forestry purposes in the southern half of the province, then it is invariably taken away from the provincial forest.

The forestry establishment is not working to protect its resource against wilderness alone. They are just as anxious about lands lost to hydro, agriculture and urban sprawl. The great anxiety in the forestry establishment is caused by the taking by the trend... not the thing its being used for. Gone is gone

Within biological limits, renewable resources like forests, rangeland, wildlife and fisheries can be managed to provide benefits in perpetuity. In BC we are getting better at it all the time and in some areas we are right up there with the world leaders. But it will be more and more difficult to attain these objectives if we continue to erode the land base on which these resources depend.

The problems also grow geometrically, for the loss of a chunk of land to wilderness (or an other single use) automatically increases the pressure on the lands which remain. In other words, when a wilderness area is established in a provincial forest, land use conflicts will increase rather than decline. 
Here's another point to ponder. Special interests like wilderness lobbies need only concern themselves with their own objectives and they have no real public accountability at all. Resource agencies are accountable to government and ultimately to the general public with all its special interests. They must consider each individual demand but also the sum of them all.

Wilderness does for us what no other social value can do. We must have it. Not to satisfy the wilderness lobbies alone, for reasons much more vital than that. But wilderness is not free! Ultimately, its value will be measured by how much people are willing to give up to have it.

The general public, and I suspect most wilderness lovers as well, have expectations that the social benefits derived from multiple use resource management will continue indefinitely if not increase over time. If we set more and more areas aside for wilderness, these other expectations must be lowered proportionately. We can't have it both ways.
I believe we should have more wilderness. I believe our society will benefit from having consciously decided to leave some places alone. I am prepared to make some social sacrifices in order for that to happen. But I can only make that decision for myself, I have no right to make it for the World.

So from my standpoint the course we must follow is quite clear. We must have a broadly-based, detailed public inquiry into wilderness in BC. We must allow all sides to be heard. The input can be used to formulate a provincial wilderness policy for BC. Let the debate begin.

\title{
The Forester as Salesperson
}

by

\author{
Alex Dickson
}

Because people generally take the forest and its benefits for granted, they often fail to practice or support forestry when the opportunity presents itself. If this situation is to be remedied, the forester must learn to promote the forest's worth To do this, he must become a salesperson - a forest salesperson. And, to be an effective forest salesperson, he must use the combined skills of a public relations practitioner, communicator. sociologist and psychologist.

There are three factors which are common to successful selling:

1) The salesperson must be seen by the would-be buyer as honest and trustworthy. Development of that favourable image is the result of good Public Relations (PR).

2) He must be able to communicate effectively with the potential purchaser. This involves some knowledge of communication theory

3) He must be able to relate his product to the felt needs and interests of his customer. To do this, he has to know his product and something about "what makes people tick

Let us now look at each of these factors and determine how the forester might become more of the salesperson he needs to be.

\section{Public Relations}

First of all does a forester have public credibility? How do people see him? Is he perceived as a modern-day Paul Bunyon with muscles, double-bitted axe and a "foul mouth"? Is he seen as a tree planter or forest-fire lookout? Or, is he regarded as the professional, scientific college graduate he is?

The American Forest Institute, some years ago, found that foresters generally had an enviable reputation in terms of credibility. It would behoove them, however, to try to keep it that way by consciously observing some of the principles of good PR.

The whole purpose of PR is to relate effectively to people. This means that people have to know, understand and agree with what foresters do. At one time the barons of business declared that what they did was of no concern to anyone but themselves. Are foresters tending to take this same autocratic stand? Worse still are foresters the handmaidens of the modern-day "barons"? In our presen highly interdependent society, today's public opinion can be tomorrow's legislation. Therefore, the forester should be aware of how people see him and his role in society. (Bear in mind that he has an image whether he does anything about it or not.) If a "professional" does not show independence of thought he will not be accorded "professional respect".

The forester's character (actual situation) needs to match his reputation (how people perceive him). If it does not, then effort must be directed toward closing the gap. But it is not just necessary to do something whorthwile. The doing of that something must be brought to public attention. Now while it is true that "blowing one's own horn" is quite often considered reprehensible to modest people. not to do so - in the words of one PR textbook - is to ignore the "babble and bedlam in today's court of public opinion".
One simple definition of PR is: $P R$ is good work publicly appreciated. Another is: $P$ (for performance) $+R$ (for recognition) $=P R$. However, the one that appears to be most concisely appropriate is to be found in the 1978 edition of Cutlip and Center's Effective Public Relations:

Public relations is the planned effort to influence public opinion through good character and responsible performance, based upon mutually satisfactory two-way communication.

There are many examples of poor PR to be found in the annals of natural resources management. One that comes to mind concerns Dr. Bernhard E. Fernow who played an important part in the early development of forestry in Canada. While he was director of the first professional forestry school in the U.S. - Cornell University (1898-1903) - he antagonized his wealthy, influential Adirondack neighbours by clear-cutting, burning and planting in their northern New York playground. His proposition was to replace low-grade hardwoods with fast-growing conifers and, thus, substantially increase the yield. Time has vindicated his concept. However. because he didn't take the time to explain what he was doing to those around him, his intentions were misinterpreted and he ultimately lost his job. A sense of PR by Fernow could probably have prevented this from happening

Public relations is also common courtesy - a balance, if you like, in the Bank of Goodwill. It is most important that the withdrawals from that bank in terms of rudeness, mistakes and dishonesty, do not exceed the deposits in the form of good work done and recognized. When good 